\title{
ALIMENTAÇÃO E COMENSALIDADE ENTRE OS KANAMARI DA AMAZÔNIA OCIDENTAL*
}

\author{
Luiz Costa
}

Este artigo investiga os efeitos das relações assimétricas de maestria sobre a criação e a perpetuação do parentesco por meio da ação e da intenção humanas. "Maestria" designa um laço que envolve controle, proteção e cuidado, presente no léxico conceitual de diversos povos da Amazônia. Sua pertinência há muito é reportada nas etnografias das sociedades indígenas da América do Sul, mas só recentemente tem sido objeto de estudos comparativos de maior fôlego (Fausto 2008). A maestria é muitas vezes expressa num idioma de filiação, como a relação "pais-filhos", embora se articule de maneira complexa e etnograficamente variável com as relações de parentesco. É essa articulação que o presente artigo busca explorar.

Meu foco etnográfico são os Kanamari, grupo falante de uma língua katukina do extremo oeste da Amazônia brasileira, para quem a "fabricação social do parentesco" (Vilaça 2002:354) depende de um vínculo de maestria que é ao mesmo tempo originário e indispensável. Se, como argumenta Sahlins (2013), o parentesco é sempre a "mutualidade do ser", para os Kanamari a mutualidade é precedida pela dependência, e a ética do parentesco, pela assimetria do mestre. Ao dizer "precedência", eu me refiro a dois fenômenos relacionados: um deles é o fato de que, no que concerne ao ciclo de vida dos Kanamari, as pessoas são primeiramente inseridas em relações de maestria antes de o serem em outras relações; e o outro é que, no que concerne à teoria kanamari da relação, a maestria é precondição da mutualidade. A maestria gera o espaço no qual as qualidades intersubjetivas do parentesco podem ser vividas, e não há relações de parentesco que não sejam derivadas de laços de maestria.

Uma vez que não será possível discutir aqui todas as diferentes maneiras pelas quais a maestria determina o parentesco, limitar-me-ei ao modo pelo qual o parentesco é articulado a uma distinção central, que opõe duas modalidades de distribuição e consumo de alimentos entre os Kanamari. De um lado, o ato de alimentar ou dar de comer, que define ou expressa uma 
relação de maestria. De outro, a "comensalidade", que caracteriza as refeições comunais cujo sentido é produzir e propagar as relações de parentesco, possíveis somente como consequência de atos prévios de alimentação. Esta distinção é explicitamente reconhecida pelos Kanamari, e a expressão verbal em sua língua implica duas diferentes, mas interdependentes, possibilidades de relação com o outro.

Para efeitos de análise, "parentesco" define duas qualidades sobrepostas, consideradas pelos Kanamari como parte integral das relações mútuas entre "parentes" (-wihnin). A primeira é a corresidência, -wihnin-to ("viver junto, viver com os parentes"). A corresidência pode indicar a coabitação em uma mesma aldeia, mas não necessariamente. Ela implica, no mínimo, a coabitação em um aglomerado de aldeias próximas, articuladas em torno de uma maloca, unidade que designo pelo termo "subgrupo". A corresidência delimita um universo de pessoas que mantêm interações contínuas de tipo não ritual.

A segunda qualidade do parentesco é abrangida pela expressão kanamari ityonin-tikok, que traduzo, de forma literal, por "conhecer a terra". Ityonin-tikok parece ser a variante kanamari de um conceito comumente registrado na Amazônia indígena, e em geral glosado (por antropólogos) como um "estado comunitário de bem-viver". Termos indígenas análogos são frequentemente traduzidos por expressões como "viver bem", "boa vida", "tranquilidade" ou "convivialidade" (ver Belaunde 2001; Overing \& Passes 2000). Pessoas que "conhecem a terra" são aquelas que convivem em harmonia, através de valores como "afeto" (wu), "beleza" (bak) e "felicidade" (nobak), qualidades que devem vigorar entre "corresidentes". Ityonin-tikok é um conceito complexo, imbricado na não menos complexa ética da vida social kanamari, e cujo entendimento profundo requer um estudo à parte. Neste artigo, tratarei exclusivamente de uma de suas facetas principais, o "afeto" (Lepri 2005:714). ${ }^{1}$

De início, pretendo mostrar que as relações baseadas na comensalidade e no afeto originam-se da alimentação e da maestria. Em seguida, irei demonstrar que o ciclo de desenvolvimento das relações, que vai da alimentação e da maestria para a comensalidade e o afeto, desenrola-se dentro de uma estrutura que é, ela mesma, determinada pela primazia do laço criado pela alimentação. Na conclusão, analiso a origem da alimentação tal como postulada no mito, para mostrar que se ela tem precedência filogenética e ontogenética sobre a comensalidade, isto decorre, por sua vez, de uma relação anterior de predação, que vem constituir os laços primordiais de maestria dos quais deriva o estado presente.

Meu trabalho de campo foi realizado com os cerca de 430 kanamari que habitavam as margens do rio Itaquaí, na Terra Indígena do Vale do Javari, 
entre 2002 e 2006. O Itaquaí é um afluente do Javari, mas seu curso superior é acessível, pela vertente, a partir dos afluentes da margem esquerda do médio Juruá, onde atualmente vive a maioria dos mais de 3.100 Kanamari. Existem diferenças etnográficas importantes entre os Kanamari de diferentes regiões (veja-se Reesink 1993; Carvalho 2002) e, por isso, devo realçar que esta análise se refere especificamente aos Kanamari do Itaquaí. Sua pertinência para os demais Kanamari precisaria ser demonstrada por novas pesquisas de campo.

\section{Alimentação}

A palavra kanamari para "alimentar [alguém]" ou "dar de comer [a alguém]", ayuh-man, contém a raiz ayuh, que indica a necessidade de algo ou de alguém. Em sintagmas verbais, esta raiz funciona geralmente como verbo auxiliar modal, tal como aparece em ayuh-dok ("ter necessidade de defecar" ou "precisar defecar"), e ayuh-pok ("ter necessidade de fazer sexo"). Nestes exemplos, ayuh indica uma necessidade mecânica, sobre a qual as pessoas têm pouco controle. Os Kanamari que falam português costumam traduzir a raiz ayuh, nestes casos, pelo verbo "precisar".

Ayuh também pode ser empregado como verbo não modal. É o caso, precisamente, de ayuh-man, em que ayuh se liga ao verbo polissêmico -man, que significa "fazer, executar, fabricar, obter", mas também "dizer". No caso de ayuh-man, -man funciona como causativo. ${ }^{2}$ Diferentemente do que ocorre com outros sintagmas verbais contendo ayuh, não se inclui a palavra "precisar" em traduções de ayuh-man para o português. Ao contrário, os Kanamari sempre me traduziram ayuh-man por "dar de comer", embora o sentido literal ou etimológico do termo seja "causar necessidade" ou "fabricar/criar necessidade".

Igualmente ao que se passa em qualquer evento causativo, ayuh-man expressa uma macrossituação que constitui duas microssituações: o agente da causa alimenta, o paciente da causa é alimentado (ver Comrie 1981:165166). Em geral, o resultado concreto de ayuh-man é que o participante alimentado termina por "comer" ( $\mathrm{pu}$ ) a comida oferecida pelo outro. Contudo, como a análise linguística indica, o verbo ayuh-man não enfatiza o "comer" como o principal objetivo da alimentação. Devemos, pois, nos perguntar: se ayuh-man é um causativo que não (apenas) conduz ao ato de comer, o que, afinal, ele causa no outro?

Levar o outro a comer é, na verdade, um método para causar nele uma necessidade em relação à pessoa que o alimenta. Os Kanamari dão a esta 
necessidade o nome-naki-ayuh, no qual -naki funciona como a preposição "em", com o significado de "dentro de". -Naki-ayuh indica uma "necessidade interna". Não se trata de uma "necessidade" genérica, mas sim de uma necessidade pela pessoa que alimenta, que podemos caracterizar como uma "dependência". A frase Kamanyo na-naki-ayuh awa niama, por exemplo, significa "Kamanyo precisa [depende] de sua mãe". O que está implicado aqui é uma necessidade constitutiva, eventualmente vital. Sendo assim, a alimentação não é um ato que encerra uma necessidade prévia (por exemplo, a fome). É, ao contrário, um ato que cria ou perpetua uma necessidade. Em outras palavras, se tanto o verbo "alimentar" em português quanto o verbo ayuh-man em kanamari são causativos, o primeiro encerra-se em um ato de comer, enquanto o segundo conduz a uma necessidade e a uma dependência que se estendem no tempo.

"Alimentar" implica um conjunto heterogêneo de eventos e atos, que incluem: amamentar; alimentar xerimbabos; ${ }^{3}$ transformar alimentos crus em refeições cozidas a serem servidas em festas coletivas; constituir um ambiente físico e moral onde os alimentos são distribuídos; fornecer a terceiros os meios necessários para que obtenham alimentos por conta própria (por exemplo, espingardas, anzóis, terçados); e ainda conhecer e executar os cantos rituais que tornam possível a reprodução da flora e da fauna.

Os atos e os eventos descritos em termos de "alimentação" são característicos das relações entre parentes, mas não se limitam a elas, podendo-se efetivar entre pessoas que mantêm relações dos mais variados tipos. Porém, uma vez estabelecida, a relação alimentar altera a natureza do vínculo prévio. As relações mais frequentemente associadas a ayuh-man incluem aquelas entre as mulheres e seus animais de estimação, entre pais e filhos, entre xamãs e seus espíritos auxiliares, entre chefes e seus seguidores, e entre a Fundação Nacional do Índio e os Kanamari. A alimentação pode ainda caracterizar certos aspectos da relação entre marido e mulher, ou entre homens e mulheres de maneira geral, ${ }^{4}$ bem como entre um professor e seu aluno (por exemplo, entre um caçador experiente e o jovem que o acompanha na caçada, ou entre um xamã e seu aprendiz). Em todos estes casos, diz-se que o primeiro "alimenta" o segundo.

Um rápido exame desta lista é suficiente para mostrar quão infrutífero seria buscar uma definição substantiva ou exaustiva de ayuh-man. Talvez seja melhor definir o termo em oposição à "troca de comida" (tyawaihmini hom) entre não parentes, e à "comensalidade" (da-wihnin-pu) entre parentes durante as refeições cotidianas. Diferentemente destes dois contextos interacionais, a alimentação não pode ser definida nem como partilha ou troca de alimentos entre pessoas adultas que possuem a capacidade de produzir 
ou obter comida por conta própria, nem como uma prática de subsistência comum às interações do dia a dia. Isto porque, como já notei, aquilo que os Kanamari chamam de ayuh-man cria uma relação assimétrica entre aquele que alimenta e aquele que é alimentado, o que não significa que a alimentação não possa, em certos contextos, caracterizar laços entre adultos plenamente produtivos. Mas quando outras relações são obviadas em prol da relação alimentar, é porque se está sublinhando a capacidade produtiva suplementar daquele que alimenta vis-à-vis àquele que é alimentado. Ao focalizar-se a relação alimentar em detrimento de outros tipos de relação, um adulto plenamente produtivo é feito dependente, isto é, constituído - no contexto dessa relação - como alguém incompletamente produtivo.

Assim, embora os Kanamari costumem traduzir ayuh-man por "alimentar", várias das ações que descrevi acima não se parecem muito com aquilo que nós, normal e literalmente, entendemos por alimentação, mesmo considerando que todas elas mantenham alguma conexão, tênue que seja, com o ato de prover alguém com os meios físicos ou as matérias-primas necessárias para que esta pessoa seja capaz de produzir comida para si mesma. No limite, porém, ayuh-man não precisa estar associado às atividades de subsistência ou ao ato de comer. Fazer uma pessoa comer dando-lhe alimento ou provendo-lhe os meios de produzir o próprio alimento é apenas um caso privilegiado de uma relação assimétrica muito mais geral, na qual um participante torna disponível ao outro aquilo que lhe era previamente indisponível, com isso criando (ou ampliando) uma dependência deste último em relação ao primeiro.

\section{Os xerimbabos}

Assim como muitos outros povos indígenas da Amazônia, os Kanamari capturam e criam os filhotes de animais mortos em caçadas. Esta prática é um exemplo do que Fausto denominou "predação familiarizante", expressão que designa o "processo pelo qual sujeitos capturados no exterior são consumidos e controlados com o objetivo de se produzirem novos sujeitos no interior do grupo" (Fausto 1999:949). Para os Kanamari, a alimentação é o meio pelo qual esse controle se estabelece, sendo um momento importante na produção de pessoas (ou, adiantando-me um pouco, na produção de pessoas que produzem e/ou consomem). Focalizar o modo como os xerimbabos são criados é um bom ponto de partida para uma discussão etnográfica sobre a alimentação, visto que a relação entre mestre e xerimbabo é definida primordialmente pelo ato de dar de comer. Sendo um exemplo paradigmático, 
a criação de animais de estimação nos permite identificar claramente os efeitos da alimentação, possibilitando isolar esses efeitos em contextos nos quais ela aparece entremeada a outras relações.

Acima, observei que os Kanamari falantes de português traduzem ayuhman por "dar de comer". Mas, quando eu lhes perguntava diretamente o que é ayuh-man, muitos deles respondiam por meio de um exemplo mais preciso: "ayuh-man é quando uma mulher mastiga a comida, tira da boca e a coloca na boca do animal que ela está criando". A palavra kanamari para xerimbabo é bara o'pu, que significa literalmente "pequeno animal". O termo é usado para se referir tanto aos filhotes em estado selvagem quanto aos xerimbabos. Neste último caso, o uso da palavra independe da idade do animal. Normalmente, os animais de estimação dos Kanamari não vivem muito, mas aqueles que chegam à idade adulta seguem sendo chamados de "pequeno animal", continuando a marcar, assim, sua condição dependente.

Em casos concretos, a raiz nominal bara pode ser substituída pelo nome da espécie sendo criada. ${ }^{5}$ Embora sejam os homens os caçadores, normalmente são as mulheres (e ocasionalmente as crianças) que alimentam e criam os animais de estimação. Esta é uma divisão do trabalho comum em toda a Amazônia (ver Erikson 1987; Taylor 2001; Cormier 2003:114-115). O papel das mulheres na familiarização de animais é expresso na própria palavra para animal de estimação, visto que o morfema o'pu ("pequeno"), quando precedido por um prefixo possessivo, transforma-se no termo de parentesco para "filho" na terminologia feminina (veja-se, também, Vander Velden 2012:165). De fato, bara o'pu pode ser traduzido tanto por "pequeno animal" quanto por "animal-filho" (m.f.), realçando, desta forma, a associação entre pais-filhos (neste caso, mãe-filho) e dono-animal de estimação — associação, aliás, bastante recorrente na Amazônia (Fausto 1999). ${ }^{6}$

Outro nome comum para xerimbabo é ityowa tyuru-tiki-yan, que poderíamos traduzir por "aquele que fazemos crescer/desenvolver" ou "aquele a quem causamos o crescimento/desenvolvimento". Este termo enfatiza o vínculo vital entre o animal e seu dono humano, estabelecido pela alimentação. ${ }^{7}$ Quando falo de laço ou vínculo vital, estou me referindo ao fato de que o animal de estimação não sobreviveria sem os cuidados e a alimentação providos por seu dono. Dar de comer é a técnica central da familiarização de animais, visto que, uma vez que o filhote aceita ser alimentado, considera-se que ele não poderá subsistir doravante fora do âmbito do vínculo ali estabelecido. A alimentação, além disso, não é apenas a provisão de comida, mas um processo que acarreta uma mudança na dieta do animal, já que ele deve aprender a aceitar um tipo de comida consumido pelos humanos e preparado pelas técnicas culinárias humanas. Isto muitas vezes pode incluir 
a carne cozinhada da própria espécie que está sendo familiarizada (Erikson 2011:22). O novo paladar adquirido pelo animal de estimação aprofunda sua identificação com o dono, sendo mais um fator a prevenir possíveis fugas (ver também Déléage 2009:191; Goulard 2009:215-216).

Embora seja a técnica central de familiarização, a alimentação ocorre juntamente com uma série de outros mecanismos. Quando um caçador traz um filhote de animal para a aldeia, toma o cuidado de remover-lhe os dentes e, caso necessário, também as garras; se for uma ave, suas asas são de imediato podadas. Em seguida, se for um mamífero ou um réptil, ele é amarrado por uma corda a um poste no interior da casa; se for um filhote de pássaro, é colocado dentro de uma cesta de palha onde permanece aquecido. Periodicamente, solta-se o bicho para que ele possa receber a fumaça dos fogos da casa, pois assim ele vai se acostumando aos odores de sua nova morada e perdendo a vontade de fugir.

Todos os bichos de estimação são alimentados inicialmente com mingau de banana, caiçuma (não fermentada) de mandioca doce, ou com uma bebida feita do fruto da pupunha. A comida inclui também pedaços de banana, mandioca ou pupunha, sempre previamente mastigados pelas donas antes de serem colocados diretamente nas bocas ou nos bicos dos xerimbabos. Pouco a pouco, os pássaros vão aprendendo a comer na palma da mão das donas e os mamíferos desdentados passam a comer restos intencionalmente jogados no chão, perto do poste a que foram atados. Mais tarde, quando forem soltos do poste, comerão nos pratos de sua dona, o que ocorre sobretudo com macacos. Durante os primeiros dias, a dona do animal, responsável por seu bem-estar, deve abster-se de ingerir carne de caça, principalmente carne da mesma espécie do animal capturado (se for um animal comestível). Alguns Kanamari me disseram que a abstenção não vale apenas para a dona do animal, mas para todos os residentes da casa.

Submetido a esse processo, o animal passa gradualmente de um estado selvagem, ou "da floresta" (ityonin-warah) para um estado doméstico ou "da casa" (hak-warah). É quando, por fim, ele é desamarrado do poste e começa a circular livremente pela aldeia. $\mathrm{O}$ animal está plenamente familiarizado quando perde a capacidade de sobreviver fora do grupo doméstico e se torna dependente total do seu dono. À medida que a relação progride, a alimentação pode se fazer acompanhar de sentimentos que parecem, a princípio, atenuar a dependência original ou, pelo menos, dar-lhe outros contornos. Um desses sentimentos é o "afeto" $(w u)$. O verbo kanamari wu implica uma orientação mútua entre aqueles que têm afeto um pelo outro. $O$ termo parecer conotar, assim, uma relação de simetria ou mutualidade contrária à assimetria ou maestria inerente ao vínculo criado pela alimentação. 
No restante desta seção tratarei de mostrar que, no desenvolvimento da relação mestre-xerimbabo, a alimentação é a precondição para que possa emergir um sentimento recíproco de afeto.

Quando uma mulher começa a alimentar seu animal de estimação, ela costuma anunciar que irá "produzir a velhice dele" (a-kidak-bu), querendo dizer com isso que sua intenção é cuidar do xerimbabo por um período longo, durante o qual envelhecerão juntos. Passados alguns meses, algumas mulheres começam a colocar seus animais de estimação para dormirem consigo na rede, e demonstram afeição pelos animais que a seguem pela aldeia durante as atividades cotidianas. Aos olhos das outras pessoas, o animal acompanha sua dona porque a "ama" (wu).

Nesse estágio da relação, as donas passam a se referir a seus animais de estimação por meio de um vocativo que é utilizado de forma padronizada para todos os indivíduos familiarizados da espécie, o que Dienst e Fleck (2009) designaram pet vocative. ${ }^{8}$ Quando passam a ser chamados por este vocativo, pode-se ocultar a relação de alimentação, dizendo-se apenas que os animais de estimação "comem" ( $p u)$ a comida que as pessoas preparam para si mesmas, tomando muitas vezes o alimento diretamente do prato ou das panelas. Por ocasião da morte de um animal de estimação muito querido, as mulheres podem entrar em "luto" (mahwanin, que os Kanamari traduzem por "saudade"). O luto é caracterizado pela suspensão do trabalho, pela abstinência alimentar e pela explosão periódica de lamentos e prantos, nos quais o vocativo usado para designar o animal em questão é várias vezes repetido. Certa vez, quando mostrei a um homem uma fotografia em que sua esposa aparecia ao lado de seu falecido macaco de estimação, ele me pediu que não lhe mostrasse a foto em hipótese alguma, senão ela retomaria o luto, mesmo já tendo se passado mais de um ano desde a morte do animal.

Todos os xerimbabos são criados por atos de alimentação, mas nem todos recebem de suas donas o mesmo afeto. Muitos morrem cedo, algumas poucas semanas ou meses depois de serem levados à aldeia. São então descartados, sem cuidados especiais, nos rios ou na mata. Em outros casos, os animais são alimentados apenas esporadicamente e com desleixo, vindo a morrer ou fugindo sem causar qualquer comoção ou tristeza. Há ocasiões em que os animais permanecem, mas sem serem "amados". A dona os alimentará de vez em quando, mas nenhum outro cuidado lhes será dispensado, não criando, assim, qualquer vínculo de intimidade. Nesses casos, o animal pode vir a ser trocado com outros índios ou com vizinhos brancos, e pode acabar morto e comido. ${ }^{9}$ Alguns animais tornam-se quase "vira-latas", sem dono, ao serem ignorados por aqueles que originalmente os alimentavam. Os Kanamari dizem, em português, que esses animais são da comunidade. 
Isto não significa que eles são de todo mundo, mas ao contrário, que eles não são de ninguém, que ninguém se responsabiliza por eles (cf. Fausto 2008:355, nota 13). O que resta a esses animais é vagar de casa em casa, comendo sobras e surrupiando comida. ${ }^{10}$

Quando existe afeto entre o mestre e o xerimbabo, esse sentimento pode ser retraçado a um laço de alimentação originário. Mas, como acabo de afirmar, nem todo ato de alimentação resulta em afeto. Todo ato de alimentação implica, isso sim, dependência (-naki-ayuh). A relação entre a dona e o animal de estimação por ela alimentado é aquela em que a primeira detém o controle sobre o destino do segundo. Em certo sentido, ela é a fonte de sua vida. Enquanto dura a alimentação, a dependência do animal persiste.

\section{Maestria}

Quando passamos da discussão dos atos causais que estabelecem a assimetria para as categorias geradas por meio deles, encontramos a variante kanamari da categoria do "dono-mestre" (Fausto 2008). Para os Kanamari, quem quer que alimente o outro é o "mestre" daquele por ele alimentado. A palavra kanamari que traduzo aqui por "mestre" é -warah, palavra que tem um escopo semântico maior do que esta tradução sugere. Para abarcar os sentidos de-warah, temos que incluir pelo menos dois significados distintos: o "corpo (vivo)" de pessoas ou animais; e o "mestre" ou "dono" de algo ou alguém. ${ }^{11} \mathrm{Na}$ língua kanamari, estes significados não são alternativos. Eles sempre ocorrem simultaneamente. Assim, para traduzir -warah, proponho o vocábulo composto "corpo-dono", juntando as duas palavras mais utilizadas pelos próprios Kanamari quando, incentivados pelo etnógrafo, arriscam uma tradução de-warah em português. Assim, podemos ser mais precisos e dizer que alguém que alimenta um outro é um "corpo-dono" desse outro (ver Costa 2010).

Uma mulher, por exemplo, é o corpo-dono do seu animal de estimação. Para se referir a essa mulher em relação ao seu xerimbabo, as pessoas dirão que ela é $a$-warah, ou seja, "seu corpo-dono". O bicho de estimação, por sua vez, não é o corpo-dono de ninguém, nem de coisa alguma. Não há como fazer referência exclusiva a ele por meio do conceito de "corpo-dono" sem subsumi-lo à dona que o alimenta. Ele pode ser chamado simplesmente de "xerimbabo" (bara o'pu), condição, como expliquei acima, que necessariamente implica a relação de maestria. Ou então, pelo termo vocativo, caso ele esteja plenamente familiarizado e viva na aldeia há algum tempo. Isto significa que o corpo-dono do animal é a mulher que o alimenta, e que fora dessa relação ele carece de um corpo-dono. 
-Warah é a única palavra kanamari para se referir ao corpo vivo, humano ou animal. Sendo assim, pode parecer estranho que o xerimbabo não tenha um "corpo" fora de uma relação. Mas é que -warah significa a objetificação de uma relação assimétrica e não uma entidade substantiva definida por sua fisicalidade. ${ }^{12} \mathrm{~A}$ assimetria objetificada pelo termo não é apenas uma característica das posições estruturais em um esquema relacional. Ao contrário, ela tem efeitos concretos na própria constituição dos termos em relação. Em uma dada relação e em um dado contexto, -warah é o termo que tem a capacidade de agir com e pelos outros termos da relação, alinhando as atividades destes últimos às suas (Strathern 1988:274-288). Nesse sentido, o "corpo-dono" exprime aquilo que a antropologia do final do século XX passou a chamar de "agência" (agency) (ver Ortner 2006:134137). Na antropologia, "agência" é um conceito de definição variável, "um quadro culturalmente prescrito para se pensar sobre a causação" (Gell 1998:17). Para os Kanamari, a agência não é inerente aos indivíduos. Ela resulta de uma objetificação, por meio de um afunilamento e uma coordenação das atividades de outros, para uma finalidade coletiva específica. $\mathrm{O}$-warah emerge de um laço e, no contexto deste laço, determina a natureza de atividades.

Em sua discussão sobre o parentesco como "mutualidade do ser", Sahlins enfatiza que da mesma forma que o parentesco torna a experiência "transpessoal", difundindo-a diferencialmente entre aqueles que são parentes, a agência é "uma função da conjunção, localizada na relação e como a relação que ela realiza em ato. A agência está na unidade da dualidade" (Sahlins 2013:52-53). Adaptando a fórmula de Sahlins para a constituição da agência, podemos dizer que, para os Kanamari, a relação que evidencia a agência é assimétrica, e a ação que resulta da conjunção de pessoas é infletida na direção do participante que alimenta outro ou outros e que, por isso, ocupa o extremo englobante da "dualidade", determinando assim a sua direção. ${ }^{13}$ Os "corpos" somente são referidos enquanto loci de atividade, isto é, quando sujeitos agem sobre (ou interagem com) outros em relações específicas de assimetria. Isto quer dizer que, para os Kanamari, um corpo individual, solitário, nunca se materializa realmente, já que qualquer atividade em que o corpo-dono esteja presente exige pelo menos dois participantes, um dos quais será o corpo-dono do outro ${ }^{14}$ Portanto, na relação de familiarização de animais, a mulher que alimenta é o corpo-dono do animal alimentado, e este não sobreviveria sem os cuidados dela.

Já demonstrei acima de que modo a dependência do termo subordinado para com o termo englobante opera na relação de familiarização do animal de estimação. Isto se aplica, com algumas variações, a todos os laços de corpo- 
dono criados pela alimentação. Se considerarmos, por exemplo, a relação entre mãe e filhos, dando mais ênfase ao laço corpo-dono do que a outros aspectos da relação, é possível referir-se ao termo englobante (neste caso, a mãe) por meio das seguintes expressões: $a$-warah ("seu [dele] corpo-dono"); awa opatyn-na-warah ("corpo-dono de sua criança"); ou "x-warah" (onde " $x$ " é o nome próprio da criança). Note-se que a construção que incorpora o nome próprio da criança remete à figura da mãe, e não ao seu filho. Não há como se referir exclusivamente ao "corpo" de um recém-nascido por meio do -warah (como também não há forma de se referir exclusivamente ao "corpo" de um animal de estimação), já que ele ainda não está envolvido em relações nas quais seja um corpo-dono de alguém. A mãe é o corpo-dono de seu filho porque é ela quem o alimenta, primeiro com o leite materno, e posteriormente com a comida que cozinha. A criança não é produtiva e em nada contribui para a subsistência ou para a manutenção cotidiana do grupo doméstico. Conforme observação de Peter Gow (1989:578) sobre os Piro, qualquer tarefa desempenhada por uma criança não passa de um complemento auxiliar à atividade dos adultos. ${ }^{15}$

Para crescer e se desenvolver, a criança precisa ser alimentada pela mãe. $\mathrm{Ou}$, para ser mais exato, qualquer mulher que lhe dê comida torna-se sua mãe (niama), visto que é ela quem permite seu crescimento e desenvolvimento. ${ }^{16}$ Mas, no processo de crescimento, a criança desenvolve paulatinamente seus próprios laços de corpo-dono, à medida que aprende a fornecer comida (um pouco de peixe ou frutas silvestres) a seus irmãos mais novos e/ou se torna responsável pelo cuidado de bichos de estimação. O desenvolvimento de laços corpo-dono é sinal de amadurecimento e parte integrante do ciclo de vida de todas as pessoas. Ser um adulto humano implica estabelecer e manter laços corpo-dono com outrem.

Paralelamente, à medida que uma pessoa vai aos poucos se tornando produtiva, ao fazer-se corpo-dono de outros, aqueles laços corpo-dono que a constituíam previamente começam a se atenuar ou a derivar para tipos mais simétricos de relação, como o "afeto", que obvia o laço assimétrico de dependência estabelecido anteriormente. Um homem adulto pode amar sua mãe, mas não tem a mesma necessidade dela como quando era criança, pois ela não mais o alimenta. Esse homem, já plenamente capaz de produzir sua própria comida e apto a alimentar-se, torna-se, por sua vez, um corpo-dono de outros. Isto não significa, é importante ressaltar, que ele não venha a se encontrar em posição subordinada em relação a terceiros que atuam, em certos contextos, como seus corpos-donos. Significa, isto sim, que tais situações escasseiam na mesma medida em que aumentam as oportunidades de assumir posições englobantes como corpo-dono. 
Ter filhos e criar xerimbabos são dois momentos privilegiados para a criação de laços corpo-dono por meio da alimentação. É amplamente atestado pela antropologia das terras baixas da América do Sul que gerar filhos é parte integral do desenvolvimento da pessoa. Até o nascimento do primeiro filho, o vínculo matrimonial é considerado volúvel e inconstante (ver, p. ex., DaMatta 1982:123-124). O nascimento do primogênito costuma marcar o afrouxamento ou o término do período de serviço da noiva, cumprido pelo marido nos regimes uxorilocais (Kensinger 1995:106; Rival 1998; SantosGranero 1991:173). Em algumas sociedades indígenas, ter filhos é o que permite a passagem para a categoria de idade dos adultos (Seeger 1981:112115). São os filhos, deste modo, que consolidam o casal enquanto unidade produtiva e estável, garantindo o sucesso das uniões matrimoniais.

Além disso, alguns autores já demonstraram que as atividades de caça, familiarização de animais e casamento baseiam-se nas mesmas premissas simbólicas (Taylor 2000, 2001; Walker 2013). No entanto, chamo a atenção para o fato de que a criação de animais também pode ser parte constitutiva do processo de amadurecimento, e que este dado ainda não foi devidamente considerado em abordagens comparativas, tampouco tentou-se extrair daí implicações mais abrangentes. ${ }^{17}$ No modelo da predação familiarizante de Fausto (1999), a familiarização de animais é obscurecida por um esquema que parece enraizado nela, mas cujo foco são relações menos prosaicas, como aquelas entre o matador e a vítima, ou entre o xamã e seus espíritos familiares - ambas tendo o efeito de desenvolver as capacidades agentivas daquele que exerce maestria sobre o outro. Como observa Taylor (2001), as relações dos humanos com seus animais de estimação são antitéticas à capacidade criativa e reprodutiva dos próprios xerimbabos, visto que estes não se reproduzem em cativeiro.Mas, por outro lado, tais relações são muitas vezes parte do desenvolvimento das capacidades criativas dos humanos ao se apropriarem de forças vitais exógenas.

No caso dos Kanamari, criar xerimbabos e dar de comer aos irmãos mais novos são os primeiros momentos em que uma criança - que foi alimentada por outros - começa a desenvolver suas próprias capacidades de alimentar. Evidentemente, há uma diferença importante entre criar animais e criar filhos. A longa maturação de uma criança e de um animal de estimação faz com que ambos só possam existir por meio do seu corpo-dono durante um período prolongado. Mas a aquisição da capacidade de criar laços de corpo-dono por meio da alimentação (mitigando assim laços prévios de dependência) é uma característica exclusiva do amadurecimento da criança, e não do xerimbabo. Embora tanto uma quanto o outro sejam novas criaturas que entram no espaço das relações cotidianas, o parentesco com o animal vai 
até um limite, posto que ele jamais alimenta um outro e tampouco é capaz de produzir alimento. Nesse sentido, as relações entre dono e xerimbabo que se desdobram em afeto e comensalidade são ficções públicas, já que não há como destacá-las de seu conteúdo subjacente ancorado nos atos de alimentação. Uma criança, ao contrário, termina por se liberar da relação de dependência com sua mãe à medida que vai criando seus próprios laços corpo-dono ao alimentar outras pessoas. ${ }^{18}$

Antes de discutir de que maneira a comensalidade difere de e se articula com a alimentação, gostaria de reiterar quatro aspectos importantes da teoria kanamari da maestria (ver também Fausto \& Costa 2013). Primeiro, uma mesma palavra designa tanto o dono quanto o corpo. Segundo, relações de maestria estão articuladas à alimentação. Terceiro, essas relações manifestam-se por meio da imagem continente-conteúdo: alimentar é conter aquilo que é alimentado; ser alimentado é ser inserido em uma relação com um corpo-dono. E, finalmente, ser "de" alguém, no sentido de que uma criança ou um animal de estimação são "de" sua mãe, é o ponto de partida inescapável do ciclo de vida, o qual permite o desenvolvimento de outras relações à medida que os laços prévios se enfraquecem e se reconfiguram. O enfraquecimento dos laços corpo-dono que constituem a criança ocorre simultaneamente à constituição de outros laços corpo-dono, desta vez pela criança, no decorrer do seu amadurecimento. Quando uma criança deixa de ser alimentada, é porque está alimentando alguém; e quando aquele primeiro laço dá lugar a outras orientações sociais, os novos laços de alimentação estabelecidos criam novas relações de dependência que vão constituir o alimentador enquanto adulto.

\section{Comensalidade}

O problema de argumentos ontogenéticos, do tipo que acabei de apresentar, é que se torna impossível estabelecer a precedência de uma relação sobre as demais sem cair nas dificuldades da regressão infinita. Por exemplo, se o amor pelo animal de estimação surge de um laço de dependência (que, por sua vez, se origina de uma relação de predação cinegética ainda anterior), uma mulher só vai criar animais de estimação se estiver, ela mesma, envolvida em relações de afeto e cuidado mútuo com seus parentes.

A teoria social kanamari resolve este problema ao estabelecer laços de alimentação menos imediatos, articulados a corpos-donos mais abrangentes. Tais laços corpo-dono são precondições para todas as relações que ocorrem dentro dos limites do parentesco. Em outras palavras, tanto os laços de 
alimentação que prendem as mães aos seus filhos e animais de estimação quanto o afeto que pode emergir dessas relações dependem da existência de outros laços de alimentação de maior alcance, que estão na origem de toda a vida social. Refiro-me aos laços entre os chefes e seus seguidores.

Os seguidores de um determinado chefe são, em diferentes graus, "parentes" (-wihnin) uns dos outros. Para compreender o conceito kanamari de "parente" e sua relação com os chefes, é preciso discutir a comensalidade, modalidade de consumo que só ocorre entre parentes. Eu já a mencionei quando abordei, acima, algumas possibilidades de desenvolvimento dos vínculos entre mestre e xerimbabo ou entre mãe e filhos, quando esses vínculos passam do domínio mais restrito da alimentação para situações menos determinadas de partilha de alimentos. Torna-se necessário, agora, especificar exatamente o que a comensalidade acarreta no curso desse desenvolvimento.

O termo kanamari que eu traduzo por "comensalidade" é $d a$-wihnin-pu. Ele pode ser decomposto no verbo pu ("comer"), precedido por da-wihnin-, expressão que os Kanamari traduzem em português por "juntos". Da-wihnin-, por sua vez, pode ser analisado separando-se a raiz wih ("um punhado", "um amontoado", "magote") do sufixo flexional -nin, que subordina a raiz ao prefixo perfectivo $d a$-. Este prefixo marca o aspecto durativo (Comrie 1976:41-44), indicando que a ação acontece em um determinado intervalo de tempo e expressando o sentido geral de "por algum tempo" ou "durante algum tempo", em contraste com a duração inespecífica que é designada pela forma não marcada dos verbos. Quando o morfema da- flexiona o verbo $p u$ diretamente (da-pu), este ganha o sentido de "lambiscar" ou "beliscar" [a comida], em vez de "comer". Igualmente, o verbo kitan ("dormir"), flexionado na forma da-kitan, adquire o sentido de "cochilar", "tirar uma soneca". Outro exemplo semelhante é o verbo nuhuk, "dar", em que da-nuhuk significa "emprestar". Pois bem, quando a expressão da-wihnin- precede um verbo, ela indica que dois ou mais participantes realizam a ação em conjunto durante um determinado intervalo de tempo especificado pelo marcador de aspecto. Por isso, $d a$-wihnin-pu pode ser traduzido quase literalmente por "comer junto (pelo tempo de duração de uma determinada refeição)".

A situação paradigmática de "comensalidade" é a partilha de comida entre adultos plenamente produtivos. Ela caracteriza as atividades de produção e consumo das pessoas capazes de produzir todo o alimento que se espera delas de acordo com a divisão sexual do trabalho: homens adultos caçam, pescam e abrem as roças; mulheres adultas coletam recursos silvestres, cultivam as roças e são responsáveis pela cozinha. Pessoas que produzem alimento e partilham refeições devem viver juntos harmoniosa- 
mente, segundo a ética de "conhecer a terra" (ityonin-titok), que tem no afeto um de seus elementos centrais. A expressão -wihnin, que forma a palavra para "comensalidade", é precisamente a mesma que os Kanamari utilizam para se referir aos "parentes". Com efeito, $d a$-wihnin-pu pode ser traduzido também por "comer enquanto parente (pelo tempo de duração de uma refeição)".

Demonstrei acima que, no ciclo de desenvolvimento das relações kanamari, há um período transitório em que a dependência e o afeto se sobrepõem. O afeto não é, portanto, uma orientação que acontece somente entre adultos produtivos. Vimos que ele também ocorre na relação dos adultos com as crianças e com os animais de estimação, que são improdutivos. Crianças e animais de estimação podem ser amados e, por sua vez, podem amar suas mães, mas não são capazes de fornecer alimento necessário às refeições cotidianas. Embora tomem parte nessas refeições, nem as crianças, nem os animais de estimação costumam receber pratos de comida. Em vez disso, a eles se permite tomar seu quinhão sempre do prato de outra pessoa (geralmente sua mãe). Assim, "um verniz de mutualidade é colocado sobre as relações assimétricas e desiguais" (Strathern 1988:90) e, pela ampliação gradual dos limites da mutualidade, as relações assimétricas irão, ao fim e ao cabo, derivar para outras formas de relação - mesmo que, no caso dos animais de estimação, estas sejam sempre incompletas e retenham um grau de ambivalência. Pelo fato de serem alimentados, não se espera que as crianças e os animais de estimação "comam junto" com os adultos. A comensalidade que eles partilham com os adultos é diminuída, ou mesmo diretamente determinada, pelas relações de alimentação, que são mais proeminentes e imediatas.

A ambiguidade inerente à sobreposição de alimentação e comensalidade é expressa por meio de gracejos ou piadas. Animais de estimação (principalmente macacos) que pegam a comida no prato das suas donas, ou das panelas da cozinha, e que se juntam às pessoas durante as refeições são motivo de zombaria. "Ele é gente (tukuna)?", perguntam os Kanamari, abrindo-se em gargalhadas; "esse bicho de estimação é nosso parente?". Ao ver o animal junto à sua dona, comendo a comida do prato dela, alguém pode se levantar e, tirando um pouco de comida da boca, colocá-la à força na boca do animal, dizendo "aqui, toma sua comida", como se o fizesse lembrar (e quiçá aos outros presentes) que ele não é, de fato, um comensal.

As crianças também são objeto de galhofas semelhantes. Quando os meninos começam a trazer para as refeições comunais algum pescado obtido no ribeirão mais próximo, ou quando as meninas ajudam as mães na cozinha, os Kanamari zombeteiam, chamando-os de "avô" (paiko) e de "avó" (hwa). 
Aqui a ênfase não está naquilo que a criança pensa ser, mas naquilo que ela um dia se tornará. A graça da piada é que ela coloca a criança no extremo oposto do ciclo de vida, deslocando-a da posição de um comensal recente (que ela é) para a de um ex-comensal (que ela será um dia). Desse modo, a piada revela a participação incipiente e irrelevante das crianças nas refeições comunais, participação esta equivalente à dos parentes mais velhos, cuja contribuição em termos de alimentos é também muito reduzida. ${ }^{19}$

Em contraste, os adultos corresidentes - que contribuem para as refeições cotidianas - "comem juntos" regularmente. Não obstante, os adultos não estão livres de se ver em posições subordinadas no bojo de determinados laços de maestria. Se a comensalidade for isolada de outras relações, ela parece diferenciar-se da alimentação na medida em que esta estabelece o corpo-dono como uma figura da agência, ao passo que a comensalidade dispersa a agência nos vários atos daqueles que participam das refeições comunais. Pelo fato de ser realizada em uma situação temporal e espacialmente apartada do laço mais imediato e direto de alimentação, a comensalidade cria a ilusão de ser independente. Todavia, entre os Kanamari, a comensalidade nunca ocorre isoladamente, e nunca é uma manifestação voluntária de um mero desejo de partilhar refeições. Ao contrário, ela acontece necessariamente em um espaço criado por atos de alimentação prévios. O que faz os adultos serem diferentes das crianças e dos animais de estimação não é o fato de que estes sejam alimentados, enquanto aqueles não o são. O que os faz diferentes é o fato de que os adultos estão mais distantes da alimentação e, portanto, menos constrangidos por aquela dependência que prende as crianças e os animais de estimação às suas mães.

\section{Chefes}

Os Kanamari reconhecem dois chefes: o chefe da aldeia (vinculado a um núcleo de povoamento ou assentamento, isto é, uma "aldeia"), e o chefe de subgrupo (vinculado a uma maloca e associado a um conjunto de aldeias). ${ }^{20}$ Ambos os chefes são chamados de-warah, "corpo-dono", por aqueles por eles chefiados, embora definam diferentes escalas de vida coletiva. Esses dois chefes e o padrão de assentamento a eles associado formam a unidade social que, seguindo outros pesquisadores, eu venho denominando "subgrupo" (Carvalho 2002; Costa 2010:173-175; Reesink 1993).

A maioria das situações de comensalidade acontece na aldeia, espaço que é inseparável do seu respectivo chefe. Uma aldeia kanamari compõese de um número variável de casas, dispostas junto a um igarapé e a uma 
roça. A identificação de uma área propícia ao roçado, bem como os primeiros esforços para derrubar e limpar o terreno delimitam o sítio de uma nova aldeia. As pessoas que trabalham na derrubada da mata, na abertura da roça e na construção das casas da aldeia fazem-no da-wihnin, isto é, "juntos" ou, literalmente, "enquanto parentes, pelo tempo de duração da atividade". A partícula de aspecto $d a$ - indica que essa "conjunção" enquanto se faz a aldeia é contingencial, mas as pessoas não se dispersam necessariamente quando o trabalho é terminado.

O regime de residência uxorilocal significa que os filhos solteiros e os genros do homem cuja iniciativa identificou o terreno da aldeia — e que será seu chefe - não têm muita opção a não ser ficar na aldeia recém-estabelecida. Mas mesmo as demais pessoas que trabalham na construção podem decidir ali ficar e viver, caso considerem que o chefe da aldeia "conhece a terra" (isto é, age com correção ética) e que sua "fala bonita" (koni baknin) é capaz de dissipar a "fala raivosa" (koni noknin) que eventualmente possa surgir entre pessoas que realizam atividades em conjunto. Pelo fato de terem trabalhado juntos e pelas relações eticamente corretas que o exemplo do chefe lhes inspira a estabelecer, os moradores de uma aldeia são "parentes verdadeiros" (wihnin tam).

Um agregado de "parentes verdadeiros" é mantido por meio da constante generosidade do chefe. A roça é aberta coletivamente e subdividida de modo que cada unidade residencial da aldeia tenha seu lote. Todavia, os Kanamari dizem que a roça é do chefe, porque foi dele a iniciativa de mobilizar as pessoas com a finalidade de limpar o terreno e abrir a roça. Logo, foi do chefe a iniciativa que permitiu aos moradores da aldeia "corresidirem" (-wihnin-to, "viver junto/como parente"). O termo baohnin-warah, "corpo-dono da roça", é a única expressão na língua kanamari que designa exclusivamente o "chefe de aldeia" (em distinção a outros corpos-donos). Para os moradores da aldeia, o chefe é simplesmente tyo-warah, "nosso corpo-dono". O nome próprio do chefe seguido de-warah é a forma pela qual os não residentes na aldeia se referem à aldeia, ao chefe, a seus seguidores, às suas roças, e tudo o que estiver a eles associado.

Embora o chefe de aldeia seja vinculado à roça, sua casa também é importante no trato da caça. Sempre que um animal é abatido e levado à aldeia, o caçador deposita-o no chão da casa do chefe, onde o animal é esfolado, esquartejado, e só então distribuído (Costa 2012). Além disso, a casa do chefe é um lugar onde há sempre um pouco de carne cozida disponível para os moradores da aldeia. É lá também que os caçadores se reúnem ao amanhecer, antes de partir para a caçada, a fim de se alimentarem, ficarem "fortes" (waman) e, assim, "suportar" (kima) a dureza da jornada. 
Desta forma, a comensalidade característica das refeições cotidianas é tornada possível graças ao chefe da aldeia: sua roça promove a agregação da aldeia; sua roça subdivide-se em áreas familiares que alimentam os que ali vivem; sua casa é o lugar em que os animais caçados são processados em porções de carne aptas a serem cozidas e consumidas; sua casa é o lugar da abundância de comida que alimenta os caçadores e lhes garante força e energia para novas caçadas. Qualquer comensalidade que se estabeleça entre os corresidentes é o resultado do consumo de alimentos possibilitado pela existência do chefe da aldeia. De fato, a contingência espaço-temporal da comensalidade, expressa linguisticamente pela partícula perfectiva $\mathrm{da}^{-}$, só pode se converter em atos mais regulares e constantes de partilha através da capacidade do chefe de alimentar continuamente os que vivem em sua aldeia, isto é, a sua capacidade de garantir a comida necessária às refeições.

O vínculo entre chefes e seguidores é, por conseguinte, condição para que, por meio da comensalidade (entre outros mecanismos), se estabeleça o parentesco entre os corresidentes aldeãos. Não há aldeamento sem chefes, e não há parentesco sem aldeamentos. Esta parece ser a conclusão inescapável da conjunção de dois fatos largamente reportados nas sociedades amazônicas e que estão estreitamente associados entre os Kanamari: 1. o parentesco é gerado ou sustentado pela corresidência (Gow 1991:165-167; Overing 1993:55; McCallum 2001:32); 2. a aldeia é inseparável do seu chefe (Rivière 1984:72-73; Heckenberger 2005:255-290; Brightman 2010:145147). Se o parentesco emerge da convivência próxima, então a ausência das condições para essa convivência só pode resultar na impossibilidade de se constituírem relações de parentesco (Guerreiro Júnior 2011:119-120). Para os Kanamari, duas pessoas tornam-se parentes uma da outra se ambas estiverem, em algum grau, subsumidas ao mesmo chefe ou, o que é dizer o mesmo, se ambas forem alimentadas por ele.

Os subgrupos são unidades supralocais que articulam aldeias estabelecidas em uma mesma bacia fluvial. Trata-se de unidades endógamas, nomeadas, localizadas nas bacias dos afluentes do rio Juruá. Os subgrupos são fisicamente compostos por dois tipos diferentes de assentamentos, organizados conforme a hidrologia das bacias. As aldeias são sempre erguidas às margens de igarapés e cabeceiras que fluem na direção do principal curso de rio, mas nunca neste. Aí é o local onde se constroem as malocas. Apenas um homem ergue sua casa nas proximidades da maloca, com sua família. Trata-se do "chefe de subgrupo". Ele é denominado tyo-warah ("nosso corpo-dono") por todos os moradores das diferentes aldeias que formam o subgrupo.

O subgrupo é o horizonte sociocêntrico do parentesco kanamari. Os corresidentes aldeãos, que reconhecem um chefe de aldeia como seu 
"corpo-dono", são "parentes verdadeiros" uns dos outros, mas são "parentes distantes" (-wihnin parara) dos habitantes das outras aldeias do mesmo subgrupo. A distinção entre parentes verdadeiros e distantes — ativada em referência a cada chefe de aldeia - é anulada quanto ao chefe de subgrupo, em relação a quem todas as pessoas que vivem na mesma bacia de rios se consideram apenas e sem especificação "parentes" (-wihnin) uns dos outros, a despeito de viverem em diferentes aldeias e igarapés. Não há parentes no exterior da área sinteticamente delimitada pela bacia do rio, pela maloca e pelo chefe de subgrupo.

Ocasionalmente, o chefe de subgrupo pode ser também denominado hak nyanin-warah, "o corpo-dono da maloca". A maloca é associada a uma roça grande (baohnin nyanin), aberta e utilizada por todos os que vivem na região da bacia do rio (isto é, todos do mesmo subgrupo), bem como a capoeiras velhas onde existem palmeiras necessárias para a sobrevivência dos Kanamari (Costa 2009:160-162). A roça grande cumpre um papel crucial na subsistência. Quando uma aldeia se desfaz, é a roça grande que sustenta aqueles que nela corresidiam enquanto contemplam a sua trajetória futura, e são variantes dos seus cultivos que os residentes de uma futura aldeia escolhem para plantar nas suas novas roças (Costa 2010:180-181). A roça grande do chefe de subgrupo é, assim, a condição das roças menores das aldeias desse subgrupo.

O traço definidor de um chefe de subgrupo, porém, é seu conhecimento dos "cantos do Jaguar" (Pidah owaik), essenciais para o ritual do "DevirJaguar" (Pidah-pa). Esse ritual ocorre em períodos em que todas as aldeias da bacia do rio se congregam na maloca. Para os Kanamari, o Devir-Jaguar garante a reprodução da fauna e da flora silvestres. Ao mesmo tempo, o ritual marca um período de colheita abundante na roça grande e nas capoeiras, bem como de expedições coletivas de caça e pesca nas quais se obtém muita carne, o que costuma resultar em grandes refeições comunais envolvendo todas as pessoas do subgrupo. Tais refeições, assim como todas as outras, derivam da existência prévia de laços de alimentação. Ao passo que o chefe de aldeia alimenta sua aldeia, o chefe de subgrupo alimenta todos os membros do subgrupo. Ele assim o faz ao garantir, por meio de seu conhecimento ritual - ou, nas palavras de Santos-Granero (1986), pelo controle sobre "os meios místicos de reprodução" - que as bases de subsistência kanamari e as matérias-primas constitutivas do parentesco estejam à disposição de todos aqueles que, pelos atos de comensalidade, são parentes uns dos outros. Se o subgrupo define o domínio em que o parentesco opera, então o chefe do subgrupo, esse hiperalimentador, é ao mesmo tempo a origem e o limite do parentesco. ${ }^{21}$ 


\section{A origem da alimentação}

Embora os antropólogos já tenham chamado a atenção para a articulação entre orientações simétricas e assimétricas na política e na ética social dos povos amazônicos (por exemplo, Gow 1989, 1991:161; Santos-Granero 1991), poucos trataram diretamente da distinção entre alimentação e comensalidade. Até onde eu sei, as exceções dizem respeito a trabalhos cuja preocupação recai sobre as diferenças entre distribuição e consumo em contextos rituais e não rituais. Vanessa Grotti, por exemplo, escrevendo sobre os Trio do Suriname, deu ênfase à diferença entre a comensalidade cotidiana, enclausurada em unidades cognáticas (Grotti 2009:80), e o que ela chama de ritual nurture, que caracteriza o alargamento da comensalidade com o objetivo de promover a conjunção temporária de pessoas previamente não relacionadas que participam de cerimônias de beberagem de cerveja (Grotti 2009, 2013). A ritual nurture funciona como uma forma de controle exercido sobre um determinado grupo de pessoas, e é considerada diferente das práticas de comensalidade que transcorrem em períodos não rituais, visto que estas últimas têm um escopo muito mais limitado no que diz respeito aos tipos de relação que elas podem gerar. ${ }^{22}$

Em contraste, a maioria dos estudos sobre práticas alimentares ameríndias concentrou-se nas diferenças entre comensalidade e canibalismo, este sendo entendido como "toda devoração (literal ou simbólica) do outro em sua condição (crua) de pessoa" (Fausto 2007:504). Se a comensalidade é o principal vetor de identificação (:502), o canibalismo é um vetor de transformação que precisa manter-se distinto dela para que o parentesco possa ser produzido. Na Amazônia, o canibalismo é uma manifestação possível do que Viveiros de Castro definiu como "predação generalizada". Mas esta última se estende para além do canibalismo, uma vez que ela é "a modalidade prototípica da Relação nas cosmologias ameríndias" (1993:184). Se, entre os Kanamari, a alimentação é a condição da comensalidade, então qual seria a ligação da alimentação com o canibalismo e a predação?

Apesar de sua natureza axiomática, a alimentação está ausente do mundo delineado pelo conjunto de mitos ancestrais que os Kanamari denominam "histórias do Jaguar" (Pidah nawa ankira). Em uma dessas narrativas, aprendemos que o Jaguar é o "corpo-dono dos peixes" (dom-warah). Esse Jaguar vivia nas cabeceiras do rio Juruá com todos os peixes, que ele devorava sozinho. O Ancestral Socó tinha permissão para pescar, mas seus cunhados, não. O Jaguar disse que os mataria caso eles ousassem pescar. Famintos, pois não havia peixe em lugar algum, eles decidem desafiar o Jaguar, sendo impiedosamente mortos por ele. O Ancestral Socó resolve 
vingar-se e mata o Jaguar. Ao morrer, o Jaguar se torna seringais. As folhas das suas seringueiras caem no rio e se transformam em peixes piau, e suas sementes em peixes pacu, que nadam rio abaixo. Os peixes agora podem viajar para várias partes do rio, mas ainda se reúnem em áreas onde há concentração de árvores seringueiras, ali se alimentando de matéria orgânica acumulada no leito do rio.

A primeira lição que tiramos desta história (e de outras semelhantes) é que, se a alimentação é uma característica do mundo presente cuja origem é explicada no mito, a maestria lhe é preexistente. Afirma-se explicitamente que o Jaguar é um -warah que contém um esquema predatório hierarquicamente organizado que constrange e limita o movimento dos peixes por ele devorados. Isto significa que a maestria só é inseparável da alimentação quando a criação de necessidades e o parentesco são isolados do quadro cosmológico mais amplo. Uma vez que o pano de fundo cosmológico é levado em consideração - como deve ser, se quisermos investigar a passagem do "discurso absoluto do mito" (Viveiros de Castro 1996:135) para o "mundo de múltiplos domínios do presente" (Fausto 2008:339) - torna-se evidente que a alimentação, da qual o parentesco deriva, é ela mesma derivada da predação, dentro de uma estrutura na qual a maestria permanece como o fator constante.

Todavia, se a arquitetura da maestria é constante, tanto no mundo mítico quando no pós-mítico, é preciso observar variações importantes no conteúdo das relações que a sustentam. No mundo mítico, a maestria não se constitui quando o Jaguar "fabrica a necessidade" (ayuh-man) dos peixes que, por sua vez, não são de forma alguma "dependentes" (-naki-ayuh) dele. Em vez disso, o Jaguar "mata" (-ti) os peixes, e estes "morrem" (tyuku) para satisfazer as necessidades do seu mestre. O Jaguar não inspira nos peixes qualquer disposição afetiva dirigida a ele, mas apenas os situa e os contém através de uma espécie de terror predatório, direcionado simultaneamente aos peixes que compõem seu corpo-dono e aos personagens que desejam os peixes. Não há parentesco no mundo do Jaguar porque não há relação de alimentação, somente a predação generalizada, que é tanto interna quanto externa aos personagens míticos.

A emergência da alimentação no mundo fenomênico é precisamente a transformação que o mito pretende contar. O corpo-dono predatório do Jaguar é transformado, depois da sua morte, em uma multiplicidade de biomas que são os corpos-donos dos peixes que alimentam. Os peixes são atraídos pelos seringais, da mesma forma que os animais de estimação e as crianças são atraídos pelas mães, e os adultos são atraídos pelos chefes. A capacidade reprodutiva ou gerativa é um dos traços definidores da maestria nas terras 
baixas sul-americanas (Déléage 2009:117-121). No mito do jaguar, notamos que as seringueiras, com suas folhas e sementes, realmente geram os peixes para, depois, passar a alimentá-los (veja-se, também, Labiak 2007:152).

Para que o parentesco exista, corpos-donos precisam alimentar outrem, emergindo, assim, como agentes em relação à passividade ou ao desamparo daqueles que são alimentados. O afeto, o "conhecer a terra" e a comensalidade somente são possíveis dentro de um espaço restrito, cujos parâmetros são delimitados por um mestre e pela dependência que este mestre causa em outrem. A comensalidade e o afeto não são relações e disposições sui genera, posto que as orientações simétricas sempre revelam suas origens assimétricas na alimentação.

No entanto, a própria alimentação só é possível num mundo que se constituiu a partir da violência predatória, no qual o parâmetro global de uma unidade singular é o canibalismo. Isto é claramente expresso nas atividades rituais do chefe de subgrupo. Os cantos do Jaguar que ele conhece são precipitados do mundo do Jaguar. O ritual do Devir-Jaguar, que o chefe de subgrupo patrocina para garantir o parentesco dos seus "filhos", é um empreendimento perigoso, por revelar algo da natureza precária do laço de alimentação, equilibrado que está entre o mundo primordial da predação universal e o mundo fenomênico da comensalidade local. Comensalidade e parentesco dependem, em última instância, da habilidade do chefe de subgrupo de replicar, no ritual, a mesma transformação da predação em alimentação narrada no mito. ${ }^{23}$

Tendo iniciado este artigo pela familiarização de animais — o vínculo paradigmático e inexorável da alimentação — é apropriado concluí-lo com o chefe de subgrupo que alimenta seus filhos no ritual, pois este é o polo menos vertical ou iminente do mesmo vínculo. Se na domesticação de animais é praticamente impossível transformar a alimentação em comensalidade, no ritual do Devir-Jaguar a comensalidade das caçadas coletivas e das refeições comunais parece ofuscar a alimentação subjacente efetuada pelo chefe do subgrupo. Reunido aos membros de seu subgrupo, seus filhos, o chefe deve incentivá-los a entoar com ele as canções que regeneram a vida abundante da floresta, assegurando assim que a comensalidade e o parentesco não fiquem para trás. Terminado o ritual, as pessoas retornam a suas aldeias, onde continuarão a caçar os animais cuja existência ele tornou possível. Continuarão a partilhar a carne, acompanhada da mandioca cultivada na roça do chefe da aldeia. Comerão juntos, como fazem os parentes.

Sem exibir a violência inequívoca que caracteriza a familiarização dos animais de estimação, os rituais do Devir-Jaguar indicam, entretanto, a violência que caracteriza o mundo primordial do mito, de onde se originou 
o estado presente de coisas. Independentemente do grau de imediatismo de suas manifestações, a alimentação é sempre a charneira entre a predação e a comensalidade, e o meio pelo qual a predação generalizada se converte em parentesco. Sua origem derivada da predação marca sua ambivalência, e sua declinação para o parentesco confirma sua necessidade.

Recebido em 15 de abril de 2013

Aprovado em 28 de setembro de 2013

Luiz Costa é professor do Departamento de Antropologia do Instituto de Filosofia e Ciências Sociais (IFCS)/ UFRJ. E-mail: <luizcosta10@gmail.com>

\section{Notas}

* Uma versão deste texto foi apresentada nos Seminários Ameríndios do PPGSAIFCS, e agradeço a Els Lagrou, Marco Antônio Gonçalves e Luisa Elvira Belaunde pelas observações. Agradeço, ainda, a Caco Xavier, Carlos Fausto, Cesar Gordon, Joana Miller, Marc Brightman e Vanessa Grotti por comentários a outras versões deste texto.

${ }^{1} \mathrm{Wu}$, que traduzo por "afeto", mas que em certos contextos pode também ser traduzido por "amor", designa uma orientação recíproca entre pessoas que participam da economia doméstica ou da economia de subsistência. Tomando emprestadas as palavras de Peter Gow (1989:580), ela é uma relação de "demanda mútua" ou de "desejo mútuo", central para as relações produtivas no regime de divisão sexual do trabalho característico das sociedades amazônicas. Wu sempre denota traços de mutualidade, reciprocidade e simetria. Quando uma relação com traços predominantemente assimétricos é formulada em um idioma de afeto, isto implica que 1. a relação assimétrica está em vias de se transformar em uma relação mais simétrica; 2 . a faceta assimétrica da relação é obviada em prol de uma faceta simétrica. Devo deixar claro que a corresidência e o "afeto" não esgotam o significado de -wihnin, "parente", e que tal ênfase neste artigo se dá em função do argumento que vou desenvolver.

${ }^{2} \mathrm{Na}$ língua kanamari os causativos podem ser formados quer pelas raízes factitivas -man e -bu, que possuem o sentido de "fazer" ou "produzir", quer pelo sufixo causativo -tiki. Enquanto este último é estritamente limitado a construções causativas, -man e -bu têm maior abrangência semântica (sobre -bu, ver Costa 
2012:104). Estes dois conjuntos de construções causativas não parecem ser gramaticalmente intercambiáveis. Embora eu não possa afirmar com toda a certeza qual das duas formas deve ser escolhida em determinado enunciado, a diferença parece estar relacionada à distinção entre causação direta (-man ou -bu) e causação indireta (-tiki) (Comrie 1981:171-174).

${ }^{3}$ Uso "xerimbabo" para designar os animais selvagens familiarizados e criados pelos Kanamari, seguindo o uso corrente na etnologia indígena. Por vezes utilizarei a expressão "animal de estimação" para designar os mesmos animais, mas não os cachorros, os gatos, nem os animais de abate (domesticados, de origem exógena) que hoje se encontram presentes em suas aldeias.

${ }^{4}$ Apesar de as relações entre maridos e esposas serem mais simétricas ou igualitárias do que as demais relações relatadas, os Kanamari dizem que os maridos alimentam suas esposas, e nunca o contrário. Uma interpretação do laço matrimonial e das relações de gênero de forma geral por meio da assimetria é recorrente no sudoeste da Amazônia. Kensinger (1995:51-52), por exemplo, afirma que entre os Kaxinawá as mulheres podem chamar os seus maridos de xaneibu, um termo utilizado para o chefe. Lorrain diz dos Kulina, vizinhos dos Kanamari, que os homens são os principais doadores e as mulheres as principais recipientes nas mais diversas esferas, referindo-se ainda ao "caráter englobante da agência masculina na produção [que é] correlacionado ao acesso primário dos homens a todos os produtos, sejam esses masculinos ou femininos" (Lorrain 2000:303).

${ }^{5}$ Os Kanamari criam uma grande variedade de animais. Durante o meu trabalho de campo, vi-os criarem antas, queixadas, caetitus, lontras, jiboias, além de pássaros e macacos. Cada um destes animais tem suas particularidades, e o processo de familiarização precisa sempre se adequar a elas. Os únicos animais que me disseram nunca criarem são felinos, serpentes venenosas, jacarés e sucuris.

${ }^{6}$ Apesar de os Kanamari demonstrarem pouco interesse pelo sexo dos animais de estimação (em contraste com o grande interesse manifestado pelo sexo dos animais caçados), o termo bara o'pu sugere que os xerimbabos são associados antes aos filhos do sexo masculino do que às filhas. No entanto, na língua kanamari, a palavra (equivalente a) "filhos" é o termo genérico não marcado para designar a prole de ambos os sexos, característica compartilhada com a maioria das línguas românicas. Assim, quando uma mulher kanamari diz i-o'pu hinuk ("meus filhos"), ela pode estar se referindo tanto aos filhos de sexo masculino, quanto aos filhos de ambos os sexos.

${ }^{7}$ Em muitas partes da Amazônia, os termos indígenas para "animal de estimação" denotam seu caráter passivo no âmbito de relações de alimentação. Por exemplo, os Huaorani da Amazônia Equatoriana chamam seus animais de estimação pelo termo queninga, que significa "aquele que é alimentado" ou "aquele que recebe comida dos humanos" (Rival 1999:79); os Barasana, grupo de língua tukano oriental do noroeste Amazônico, empregam o termo ekariera, que significa "aqueles que nós alimentamos" (Stephen Hugh-Jones apud Fausto 2007:502). 
${ }^{8}$ Assim como outras sociedades da Amazônia ocidental, os Kanamari possuem um conjunto de termos vocativos específicos que diferenciam os xerimbabos dos animais selvagens da mesma espécie (veja-se Erikson 1988:28; 2011). Todos os xerimbabos da mesma espécie são denominados pelo mesmo termo. A natureza desses vocativos varia de espécie para espécie, mas eles podem ser, por exemplo: abreviações do táxon referente ao animal em estado selvagem, nomes de personagens mitológicos, nomes de determinadas partes do animal (como "bico"), ou nomes das espécies em questão tomados de empréstimo das línguas dos grupos vizinhos (Pano ou Arawá). Independentemente da natureza do vocativo, os Kanamari dizem que eles sempre são o nome da espécie selvagem na língua dos espíritos adyaba, seres que, no mito, criam como filhos os Kanamari cativos.

${ }^{9}$ Ninguém jamais mata ou come um animal de estimação que se está alimentando. Mas pode-se dar ou trocar o animal, sabendo que ele será morto e comido por outros. Os xerimbabos podem ainda ser trocados com brancos ou vendidos para eles. Em alguns casos, o animal vendido ou dado em troca pode ser criado e alimentado pelo novo dono, passando a estabelecer com ele uma nova relação de dependência.

${ }^{10}$ Muitos etnógrafos já observaram a ambivalência que envolve a relação dos índios amazônicos com seus animais familiarizados, cuidados e maltratados, amados e desprezados ao mesmo tempo (Erikson 1987). Entre os Kanamari é impossível prever se um animal, no início do processo de familiarização, será ativamente cuidado ou passivamente ignorado. Mas essa ambivalência mencionada por outros autores não pode ser, no nosso caso etnográfico específico, isolada de considerações sobre se o animal é alimentado regularmente por seu dono, ou esporadicamente por mais de uma pessoa.

${ }^{11}$-Warah tem pelo menos outro significado importante. A palavra indica a maior parte de qualquer entidade constituída de múltiplas partes. Por exemplo, o tronco de uma árvore em relação às raízes, folhas, sementes e aos galhos. Ou o principal braço de um rio em relação a seus tributários ou formadores. Assim, -warah parece conjugar diferentes elementos em uma única entidade singular, como ficará mais claro adiante.

${ }^{12}$-Warah precisa sempre ser precedido de um nome ou um pronome que especifica aquilo que é possuído na relação (daí o uso do hífen). Sua qualidade relacional, portanto, aparece tanto no plano linguístico quanto no plano da prática social. -Warah nem sempre é usado como vocativo, pelo fato de envolver relações entre um adulto, de um lado, e seres a quem falta a capacidade da fala, de outro, como é o caso dos xerimbabos e dos bebês recém-nascidos. Entretanto, a palavra também designa a relação entre um chefe e seus seguidores. Os seguidores chamam o chefe de "meu corpo-dono" (i-warah), e são por ele chamados de "minhas crianças" (atya opatyn hinuk) ou "meu povo" (atya tukuna hinuk). Nesses casos, o nome próprio do chefe (ou, alternativamente, um pronome pessoal) seguido de-warah designa não somente o chefe, ele mesmo, mas todos aqueles que vivem com ele, bem como o próprio local onde eles todos habitam. Ver Fausto (2008:332-333) sobre as relações recíprocas de maestria. 
${ }^{13}$ Para alguns exemplos de como a agência do corpo-dono é constituída, veja-se Costa (2009:162-165; 2010:181-185).

${ }^{14}$ A palavra kanamari, que podemos traduzir por "só" ou "sozinho" (padya), significa literalmente "vazio". Pessoas "vazias" são aquelas que não estabelecem relações de alimentação ou que não são alimentados por outros. São, consequentemente, pessoas que não são "corpo-dono" de outras e que tampouco têm um "corpo-dono". É um estado perigoso que acomete, por exemplo, pessoas perdidas no meio da mata. Fora de qualquer relação assimétrica, tal pessoa corre o risco de se tornar um "espírito-alma", ikonanin, vagando errático, e não se fixando em lugar algum. O mesmo se aplica aos animais selvagens. O exemplo prototípico é o do porco-do-mato que se desgarra do bando ficando, assim, "vazio" (Ver também Fausto \& Costa 2013; Lagrou 2000; Sterpin 1993:59-60).

${ }^{15}$ A sobreposição de relações de parentesco e de maestria é um tema clássico na antropologia (ver Strathern 2006), mas apresenta alguns desdobramentos interessantes no contexto etnográfico amazônico. Entre os Kaxinawá, por exemplo, a palavra ibu, "dono", também significa "pais" e engloba tanto a noção de posse quanto a noção de autoridade legítima (McCallum 2001:33).

${ }^{16}$ Cito o exemplo de um menino que era criado pela avó materna, embora seus pais vivessem na mesma aldeia que ele. Este tipo de arranjo não é incomum entre os Kanamari (veja-se Bonilla 2007:338-344, para a importância desta prática entre os Paumari). O menino às vezes chamava a "avó" pelo termo genealógico correspondente (hwa). Mas também a chamava pelo termo niama ("mãe"), apesar de nunca ter deixado de usá-lo (niama) para se referir à sua genitora. Uma análise formal da terminologia de parentesco kanamari indicaria ser teoricamente impossível designar ao mesmo tempo as duas mulheres pelo termo niama. O sistema terminológico kanamari é de tipo dravidiano, mas estabelece algumas distinções não canônicas em G1 entre M e MZ (e entre F e FB). Essa individuação dos termos para M e F parece estar relacionada com a natureza central e exclusiva da relação corpo-dono. Chamando de niama tanto $\mathrm{M}$ quanto $\mathrm{MM}$, o menino expressava os laços conflitivos de maestria estabelecidos pela relação de alimentação que sua situação criara.

${ }^{17}$ Para uma importante exceção, ver Cormier (2003:116-117) sobre a criação de animais como parte do ciclo de vida dos Guajá do Maranhão. Veja-se, ainda, Vander Velden (2012) para uma inovadora consideração do ciclo de vida dos próprios animais de estimação entre os Karitiana de Rondônia.

${ }^{18}$ Coelho de Souza (2002:381) chama a atenção para os limites e as possibilidades dos processos de parentesco ameríndio impostos pelos diferentes regimes de alteridade e corporalidade. A diferença entre as crianças - que se tornam produtivas ao consumirem alimentos possibilitados por outras pessoas - e os animais de estimação - que permanecem indefinidamente na posição de consumidores - é a expressão kanamari dessa problemática mais abrangente.

${ }^{19}$ A piada também é endereçada aos idosos, pois assim como as crianças, eles também precisam ser alimentados (em parte, ao menos) pelos adultos. Nos limites 
deste artigo não tenho como descrever a simetria global do ciclo de vida, que faz com que os adultos deixem de ser produtivos paulatinamente, até que voltam a ser alimentados como o foram na infância. Ver Costa (2007:319-323) sobre a associação entre infância e velhice entre os Kanamari.

${ }^{20}$ A presente descrição refere-se a informações que os Kanamari forneceram sobre sua organização social no período anterior ao contato no final do século XIX e início do século XX. Tais descrições são ao mesmo tempo "históricas" (os Kanamari afirmam que viviam assim) e conceituais (afirmam que deveriam, ainda, viver deste modo, além de interpretarem as mudanças históricas a partir de coordenadas da vida social que remetem a esse passado longínquo ideal). Devo observar, ainda, que a alimentação, tal como descrita aqui, é ou continua sendo o mecanismo central na concepção das relações assimétricas, sobretudo aquelas com o Estado brasileiro. A opção por focalizar descrições histórico-conceituais nesta seção se justifica por articularem, de forma sintética, o que atualmente é mais mediado e complexo, e exigiria uma discussão mais detalhada que já forneci alhures (Costa 2007:184-196; no prelo).

${ }^{21}$ O leitor deve ter percebido que há um deslizamento em relação ao gênero do mestre quando a minha discussão da alimentação passa de mães alimentando filhos e xerimbabos em um contexto doméstico para chefes homens alimentando seus seguidores em um contexto englobante com feições "políticas". Isto parece replicar, na chave da alimentação, a oposição entre espaços "domésticos" e "públicos" que caracterizou a etnologia na década de 1970 e que vem sendo objeto de diversas críticas desde então (Graham 1993; Ewart 2003). No caso dos Kanamari, não há uma mudança qualitativa no esquema relacional que orienta a ação na passagem do "doméstico" para o "público". A alimentação, no entanto, é uma operação cuja definição paradigmática (dar comida aos xerimbabos) a associa a uma função "feminina", mas não vejo razões etnográficas para, a partir disso, afirmar que um chefe alimentando seus seguidores (ou, digamos, um xamã alimentando seus espíritos familiares) esteja se apropriando de, ou manifestando, uma agência feminina (veja-se Fausto 2007:522). O tema, no entanto, mereceria um desenvolvimento mais detalhado do que posso oferecer aqui.

${ }^{22}$ Recentemente, Grotti passou a analisar os modos pelos quais a ritual nurture opera em contextos de relação interétnica (Grotti 2013). Vale chamar a atenção ainda para as investigações etnográficas de Guerreiro Júnior $(2011,2012)$ junto aos Kalapalo do Alto Xingu, que fazem eco com a minha descrição da alimentação entre os Kanamari. Este autor tem demonstrado que as relações assimétricas de alimentação são características do chefe kalapalo, visto como "tronco" ou "esteio" de agregados sociais, possibilitando o estabelecimento do parentesco entre aqueles que dele dependem.

${ }^{23}$ Para uma análise mais detalhada do ritual Devir-Jaguar, cf. Costa (2007: 386-392). 


\section{Referências bibliográficas}

BELAUNDE, Luisa Elvira. 2001. Viviendo bien: género y fertilidade entre los Airo-Pai de la Amazonía peruana. Lima: CAAP.

BONILLA, Oiara.2007. Des proies si désirables: soumission et prédation pour les Paumari d'Amazonie brésilienne. Tese de doutorado, École des Hautes Études en Sciences Sociales, Paris.

BRIGHTMAN, Marc. 2010. "Creativity and control: property in guianese Amazonia". Journal de La Société des Américanistes, 96(1):135-167.

CARVALHO, Maria Rosário Gonçalves de. 2002. Os Kanamari da Amazônia Ocidental. História, mitologia, ritual e xamanismo. Salvador: Fundação Casa de Jorge Amado.

COElHo DE SOUZA, Marcela. 2002. O traço e o círculo: o conceito de parentesco entre os Jê e os seus antropólogos. Tese de doutorado, PPGAS/ Museu Nacional/Universidade Federal do Rio de Janeiro.

COMRIE, Bernard. 1976. Aspect. Cambridge: Cambridge University Press.

- 1981. Language universals and linguistic typology. Chicago: The University of Chicago Press.

CORMIER, Loretta. 2003. Kinship with monkeys: the Guajá foragers of Eastern Amazonia. New York: Columbia University Press.

COSTA, Luiz. 2007. As faces do jaguar. Parentesco, história e mitologia entre os Kanamari da Amazônia Ocidental. Tese de doutorado, PPGAS/ Museu Nacional/ Universidade Federal do Rio de Janeiro. - 2009. "Worthless movement: agricultural regression and mobility". Tipiti. The Journal of the Society for the Anthropology of Lowland South America, 7(2):151-180.
- 2010. "The Kanamari body-owner. Predation and feeding in Western Amazonia". Journal de la Société des Américanistes, 96(1):169-192.

. 2012. "Making animals into food among the Kanamari of Western Amazonia". In: M. Brightman, V. Grotti \& O. Ulturgasheva (orgs.), Animism in rainforest and tundra. Personhood, animals, plants and things in contemporary Amazonia and Siberia. Oxford: Berghahn Press. pp. 96-112.

_ No prelo. "Becoming Funai: a Kanamari transformation". In: Pirjo Virtanen \&Hanne Veber (orgs.), Creating dialogue: indigenous perceptions and forms of leadership in Amazonia. Denver: University Press of Colorado.

DAMATTA, Roberto. 1982. A divided world: Apinayé social structure. Cambridge, Mass.: Harvard University Press.

DÉLÉAGE, Pierre. 2009. Le chant de l'anaconda: l'apprentissage du chamanisme chez les Sharanahua (Amazonie Occidentale). Nanterre: Société d'Ethnologie.

DIENST, Stefan \& FLECK, David. 2009. "Pet vocatives in southwestern Amazonia". Anthropological Linguistics, 51:209-243.

ERIKSON, Philippe. 1987. "De l'apprivoisement à la approvisionnement: chasse, alliance et familiarization en Amazonia amérindienne". Techniques et Culture, 9:105-140.

. 1988. "Apprivoisementet habitat chez lês amérindiens Matis (langue pano, Amazonas, Brésil)". Anthropozoologica, 9:25-35.

. 2011. "Animais demais... Os xerimbabos no espaço doméstico matis 
(Amazonas)". Anuário Antropológico, II:15-32.

EWART, Elizabeth. 2003. "Lines and circles: images of time in a Panará village". The Journal of the Royal Anthropological Institute (N.S.), 9(2): 261-279.

FAUSTO, Carlos. 1999. "Of enemies and pets: warfare and shamanism in Amazonia". American Ethnologist, 26:933-956.

. 2007. "Feasting on people: eating animals and humans in Amazonia". Current Anthropology, 48:497-530. . 2008. "Donos demais: maestria e domínio na Amazônia". Mana. Estudos de Antropologia Social, 14(2):329-366. . \& COSTA, Luiz. 2013. "Feeding (and eating): reflections on Strathern's eating (and feeding)'". Cambridge Anthropology, 31(1):159-165.

GELL, Alfred. 1998. Art and agency: an anthropological theory. Oxford: Clarendon Press.

GOULARD, Jean-Pierre. 2009. Entre mortales y inmortales: el ser según los Ticuna da Amazonía. Lima: CAAP/IFEA.

GOW, Peter. 1989. "The perverse child: desire in a native Amazonian subsistence economy". Man (N.S.), 24: 567-582.

. 1991. Of mixed blood: kinship and history in Peruvian Amazonia. Oxford: Clarendon Press.

GRAHAM, Laura. 1993. "A public sphere in Amazonia? The depersonalized collaborative construction of discourse in Xavante". American Ethnologist, 20(4):717-741.

GROTTI, Vanessa. 2009. "Un corps en mouvement: parenté, 'diffusion de l'influence' et transformations corporelles dans les fêtes de bierre Trio, Amazonie do Nord-est". Journal de la Société des Américanistes, 95(1):73-96.
. 2013. "Happy with the enemy: kinship, pacification and corporeal transformation in Trio beer feasts, northeastern Amazonia". Anthropology and Humanism, 37(2):191-200.

GUERREIRO JÚNIOR, Antonio. 2011. "Esteio de gente: reflexões sobre assimetria e parentesco a partir de depoimentos de chefes kalapalo". Revista de Antropologia Social dos Alunos do PPGAS-UFSCAR, 3(1):95-126.

- 2012. Ancestrais e suas sombras: uma etnografia da chefia kalapalo e seu ritual mortuário. Tese de doutorado, Universidade de Brasília.

HECKENBERGER, Michael. 2005. The ecology of power: culture, place and personhood in the Southern Amazon, $A D$ 1000-2000. New York: Routledge.

KENSINGER, Kenneth.1995. How real people ought to live: the Cashinahua of Eastern Peru. Prospect Heights, Il.: Waveland Press.

LABIAK, Araci Maria. 2007. Frutos do céu, frutos da terra: aspectos da cosmologia kanamari no Warapekom. Manaus: EDUA.

LAGROU, Els. 2000. "Homesickness and the Cashinahua self: a reflection on the embodied condition of relatedness". In: Joanna Overing \& Alan Passes (orgs.), The anthropology of love and anger: the aesthetics of conviviality in native Amazonia. London and New York: Routledge. pp. 151-169.

LEPRI, Isabella. 2005. "The meanings of kinship among the Ese Ejja of northern Bolivia". The Journal of the Royal Anthropological Institute (N.S.), 11:703-724.

LORRAIN, Claire 1994. Making ancestors: the symbolism, economics and politics of gender among the Kulina of Southwest Amazonia (Brazil). Tese de doutorado, Cambridge University. 
- 2000. "Cosmic reproduction, economics and politics among the Kulina of southwest Amazonia". The Journal of the Royal Anthropological Institute, 6:293-310.

MCCALLUM, Cecilia. 2001. Gender and sociality in Amazonia: how real people are made. Oxford: Berg Press.

ORTNER, Sherry. 2006. Anthropology and social theory: culture, power and the acting subject. Durham \& London: Duke University Press.

OVERING, Joana. 1993. "The anarchy and collectivism of the 'primitive other': Marx and Sahlins in the Amazon". In: Cris Hann (org.), Socialism. Ideals, ideologies and local practice. London and New York: Routledge. pp. 43-58.

OVERING, Joana \& PASSES, Alan. 2000. "Introduction: conviviality and the opening up of Amazonian anthropology". In:__. (orgs.), The anthropology of love and anger. The aesthetics of conviviality in native Amazonia. London: Routledge. pp. 1-30.

REESINK, Edwin. 1993. Imago mundo kanamari. Tese de doutorado, PPGAS/ Museu Nacional/ Universidade Federal do Rio de Janeiro.

RIVAL, Laura. 1998. "Androgynous parents and guest children: the Huaroani couvade". Journal of the Royal Anthropological Institute (N.S.), 4:619-642.

. 1999. "Prey at the centre: resistance and marginality in Amazonia". In: Sophie Day, Evthymios Papataxiarchies \& Michael Stewart (orgs.), Lilies of the field: marginal people who live for the moment. Boulder: Westview Press. pp. 61-79.

RIVIÈRE, Peter. 1984. Individual and society in Guiana. Cambridge: Cambridge University Press.

SAHLINS, Marshall. 2013. What kinship is - and is not. Chicago: University of Chicago Press.
SANTOS-GRANERO, Fernando. 1986. "Power, ideology and the ritual of production in lowland South America". Man (N.S.), 21: 657-679.

- 1991. The power of love: the moral use of knowledge amongst the Amuesha of Central Peru. London: Athlone Press.

SEEGER, Anthony. 1981. Nature and society in Central Brazil: the Suyá indians of Mato Grosso. Cambridge, MS: Harvard University Press.

STERPIN, Adriana. 1993. "La chasse aux scalps chez les Nivacle du Gran Chaco". Journal de la Société des Américanistes, 79:33-66.

STRATHERN, Marilyn 1988. The gender of the gift: problems with women and problems with society in Melanesia. Berkley: University of California Press.

-2006. Kinship, law and the unexpected: relatives are always a surprise. Cambridge: Cambridge University Press.

TAYLOR, Anne-Christine. 2000. "Le sexe de la proie: représentations jivaro du lien de parenté". L'Homme, 154/155:309-334.

. 2001. "Wives, pets and affines: marriage among the Jivaro". In: Laura Rival \& Neil Whitehead (orgs.), Beyond the visible and the material: the amerindianization of society in the work of Peter Rivière. Oxford: University Press. pp. 45-56.

VANDER VELDEN, Felipe. 2012. Inquietas companhias: sobre os animais de estimação entre os Karitiana. São Paulo: Alameda.

VILAÇA, Aparecida. 2002. "Making kin out of others in Amazonia". The Journal of the Royal Anthropological Institute, 8:346-365.

VIVEIROS DE CASTRO, Eduardo. 1993. "Alguns aspectos da afinidade no dra- 
vidianato amazônico". In: Eduardo Viveiros de Castro \& Manuela Carneiro da Cunha (orgs.), Amazônia: etnologia e história indígena. São Paulo: Fapesp. pp. 150-210.

1996. "Os pronomes cosmológicos e o perspectivismo ameríndio". Mana. Estudos de Antropologia Social, 2(2):115-144.

WALKER, Harry. 2013. "Wild things: manufacturing desire in the Urarina moral economy". The Journal of Latin American and Caribbean Anthropology, 18(1):51-66. 


\section{Resumo}

Este artigo analisa o impacto das relações assimétricas de "maestria" na criação e na perpetuação do parentesco. Seu foco etnográfico são os Kanamari, povo de língua katukina da Amazônia ocidental, que distinguem entre duas modalidades de distribuir e consumir comida: "alimentação", designando uma relação assimétrica de dependência; e "comensalidade", implicando relações mútuas de partilha de comida. A segunda categoria de relações deriva da primeira, que é a base a partir da qual o parentesco kanamari se constitui. A maestria é, desta forma, lógica e ontogeneticamente anterior à mutualidade. O artigo explora essa anterioridade através de uma análise das práticas de criação de xerimbabos, e dos laços entre mães e filhos e chefes e seguidores. Explora, ainda, a relação entre "alimentação", "comensalidade" e "predação", afirmando que, para os Kanamari, a alimentação é o meio para se transformar a predação em comensalidade.

Palavras-chave Alimentação, Amazônia, Comensalidade, Kanamari, Maestria, Parentesco.

\section{Abstract}

This article analyzes the impact of asymmetrical relations of "mastery" or "ownership" on the creation and perpetuation of kinship. Its ethnographic focus is the Kanamari, a Katukina speaking people of western Amazonia, who distinguish between two modalities of distributing and consuming food: "feeding", designating an asymmetrical relation of dependency; and "commensality", implying mutual relations of sharing food. The second category of relations is derived from the first, which is the baseline from which Kanamari kinship is constituted. Mastery is hence logically and ontogentically anterior to mutuality. The article explores this anteriority through an analysis of pet keeping practices, and the bonds between mother and child and chiefs and follower. It also explores the relationship between "feeding", "commensality" and "predation", arguing that, for the Kanamari, feeding is the means for transforming predation into commensality.

Key words Feeding, Amazonia, Commensality, Kanamari, Mastery, Kinship. 